\title{
Plumbophyllite, a new species from the Blue Bell claims near Baker, San Bernardino County, California
}

\author{
ANTHONy R. KAMPf, ${ }^{1, *}$ GeOrge R. Rossman, ${ }^{2}$ AND Robert M. HOUSLEY ${ }^{2}$ \\ ${ }^{1}$ Mineral Sciences Department, Natural History Museum of Los Angeles County, 900 Exposition Boulevard, Los Angeles, California 90007, U.S.A. \\ ${ }^{2}$ Division of Geological and Planetary Sciences, California Institute of Technology, Pasadena, California 91125, U.S.A.
}

\begin{abstract}
The new mineral plumbophyllite, $\mathrm{Pb}_{2} \mathrm{Si}_{4} \mathrm{O}_{10} \cdot \mathrm{H}_{2} \mathrm{O}$, is orthorhombic with space group Pbcn and cell parameters $a=13.2083(4), b=9.7832(3), c=8.6545(2) \AA, V=1118.33(5) \AA^{3}$, and $Z=4$. It occurs as colorless to pale blue prismatic crystals to $3 \mathrm{~mm}$, with wedge-shaped terminations at the Blue Bell claims, about $11 \mathrm{~km}$ west of Baker, San Bernardino County, California. It is found in narrow veins in a highly siliceous hornfels in association with cerussite, chrysocolla, fluorite, goethite, gypsum, mimetite, opal, plumbotsumite, quartz, sepiolite, and wulfenite. The streak is white, the luster is vitreous, the Mohs hardness is about 5, and there is one perfect cleavage, $\{100\}$. The measured density is $3.96(5) \mathrm{g} / \mathrm{cm}^{3}$ and the calculated density is $3.940 \mathrm{~g} / \mathrm{cm}^{3}$. Optical properties $(589 \mathrm{~nm})$ : biaxial $(+)$, $\alpha=1.674(2), \beta=1.684(2), \gamma=1.708(2), 2 V=66(2)^{\circ}$, dispersion $r>v$ (strong); $X=b, Y=c, Z=a$. Electron microprobe analysis provided $\mathrm{PbO} 60.25, \mathrm{CuO} 0.23, \mathrm{SiO}_{2} 36.22 \mathrm{wt} \%$, and $\mathrm{CHN}$ analysis provided $\mathrm{H}_{2} \mathrm{O} 3.29 \mathrm{wt} \%$ for a total of $99.99 \mathrm{wt} \%$. Powder IR spectroscopy confirmed the presence of $\mathrm{H}_{2} \mathrm{O}$ and single-crystal IR spectroscopy indicated the $\mathrm{H}_{2} \mathrm{O}$ to be oriented perpendicular to the $b$ axis. Raman spectra were also obtained. The strongest powder X-ray diffraction lines are $[d(h k l)$ I]: 7.88(110)97, 6.63(200)35, 4.90(020)38, 3.623(202)100, 3.166(130)45, 2.938(312/411/222)57, $2.555(132 / 213) 51$, and 2.243(521/332)50. The atomic structure $\left(R_{1}=2.04 \%\right)$ consists of undulating sheets of silicate tetrahedra between which are located $\mathrm{Pb}$ atoms and channels containing $\mathrm{H}_{2} \mathrm{O}$ (and $\mathrm{Pb}^{2+}$ lone-pair electrons). The silicate sheets can be described as consisting of zigzag pyroxene-like $\left(\mathrm{SiO}_{3}\right)_{\mathrm{n}}$ chains joined laterally into sheets with the unshared tetrahedral apices in successive chains pointed alternately up and down, a configuration also found in pentagonite.
\end{abstract}

Keywords: Plumbophyllite, new mineral, phyllosilicate, crystal structure, Blue Bell claims, California, IR spectroscopy, Raman spectroscopy

\section{INTRODUCTION}

The first specimen of the new mineral species described herein was collected from adit $\mathrm{C}$ at the Blue Bell claims, near Baker, California, in 2000 by Garth Bricker of Fallbrook, California. In March of 2007, Brent Thorne of Bountiful, Utah, and Joe Marty of Salt Lake City, Utah, collected specimens of the mineral from the same site, which they made available to the authors for study. Subsequently, in October of 2007, Joe Marty and one of the authors (J.M.H.) collected additional specimens of the mineral.

The mineral is named for its essential $\mathrm{Pb}$ content and its silicate sheet structure. The new mineral and name have been approved by the Commission on New Minerals, Nomenclature and Classification of the International Mineralogical Association (IMA 2008-025). Four cotype specimens are deposited in the Natural History Museum of Los Angeles County, catalog numbers 58829, 58830, 58831, and 58832.

\section{OCCURRENCE}

The Blue Bell claims consist of a group of mostly small workings and one longer branching adit, all located on small Joe

\footnotetext{
*E-mail: akampf@nhm.org
}

Dandy Hill in the SW $1 / 4$ of section 2, T. 13 N., R. 7 E. in the Soda Mountains, about $11 \mathrm{~km}$ west of Baker, San Bernardino County, California $\left(35^{\circ} 14^{\prime} 31^{\prime \prime} \mathrm{N}, 116^{\circ} 12^{\prime} 17^{\prime \prime} \mathrm{W}\right)$. At various times in the past the long adit has been known as the Atkinson mine and most of the other workings have been known as the Hard Luck mine. Mineralization was first discovered in the area before 1885 and some of the workings were at that time mined for silver as the May Queen claim (Vredenburgh 1994). The only recorded small shipments of ore from the Blue Bell claims occurred during the interval from 1949-1951 (Wright et al. 1953; Goodwin 1957), although exploratory work apparently continued until 1958 (Maynard et al. 1984). The main values were in lead and silver, although some copper, zinc, and gold were recovered.

For several decades the Blue Bell claims have been a popular mineral collecting site. As early as 1949, roughly coincident with the first ore shipments, rich specimens of linarite, caledonite, and leadhillite were known from the deposit (Murdoch and Webb 1956). National attention was first called to the locality when John Crowley (Crowley 1977) identified and described a suite of 15 minerals that could then be found in what is now known as the A2 site or the A site glory hole. Following this, a dedicated group of volunteers from the San Bernardino County Museum, with the support of then curator of Earth Sciences, 
Robert Reynolds, made a more extensive study of the area and designated the most productive of the associated workings with letters A through F. In the most detailed available reference, they published the recent history of the region, known to them, and descriptions of 45 minerals by then identified in the combined workings (Maynard et al. 1984).

Since that study, collecting efforts have continued to yield unusual oxidation-zone assemblages of rare minerals containing a wide variety of elements, including $\mathrm{Pb}, \mathrm{Cu}, \mathrm{Zn}, \mathrm{Ag}, \mathrm{Fe}, \mathrm{Al}$, $\mathrm{Mn}, \mathrm{Na}, \mathrm{Ca}, \mathrm{Ba}, \mathrm{Sr}, \mathrm{Bi}, \mathrm{Te}, \mathrm{Cr}, \mathrm{P}, \mathrm{As}, \mathrm{V}, \mathrm{Si}, \mathrm{F}, \mathrm{Cl}, \mathrm{Br}, \mathrm{I}, \mathrm{C}, \mathrm{S}$, and $\mathrm{O}$. Some of the more significant recent discoveries have been kuksite and quetzalcoatlite (originally misidentified as tlalocite) (Housley 1997), and plumbotsumite (originally misidentified as leadhillite). The quetzalcoatite was used in the structure determination by Burns (2000), and structure determinations on the plumbotsumite (Mark A. Cooper, pers. comm.) and kuksite are awaiting publication. Plumbophyllite is the first new species to be discovered at the locality.

Plumbophyllite is found in cracks and narrow veins in a highly siliceous quartzite-like hornfels in a fractured and chaotic region of limestone showing irregular skarn formation. These cracks appear to have been initially filled largely with cerussite, silica, and/or chrysocolla. The plumbophyllite appears to be a tertiary mineral formed from the cerussite. Species observed in direct association with plumbophyllite include cerussite, chrysocolla, fluorite, goethite, gypsum, mimetite, opal, plumbotsumite, pyromorphite, quartz, sepiolite, and wulfenite. Other species identified nearby include apatite- $(\mathrm{CaF})$, beudantite, boleite, calcite, celestine, creaseyite, dioptase, ferrisurite, hemimorphite, mottramite, plumbogummite, and vanadinite. The fluorine analog of phosphohedyphane has also been noted in this assemblage and is currently under study. The conditions of formation must have been relatively basic because plumbophyllite is unstable in even weakly acidic environments.

\section{PHYSICAL AND OPTICAL PROPERTIES}

Plumbophyllite forms prismatic crystals, elongate on $c$, with wedge-shaped terminations (Fig. 1). Major forms observed are $\{010\},\{110\}$, and $\{021\}$; minor forms are $\{100\},\{120\}$, and $\{140\}$ (Fig. 2). Crystals typically occur in divergent sprays. Individual crystals are up to $3.0 \times 0.3 \times 0.2 \mathrm{~mm}$.

Crystals are colorless to pale blue and transparent with vitreous luster. The streak is white and the Mohs hardness is about 5. There is one perfect cleavage, on $\{100\}$. The fracture is splintery and although the tenacity is brittle, thin slivers are slightly flexible. The mineral is non-fluorescent. The density measured using a Berman balance is $3.96(5) \mathrm{g} / \mathrm{cm}^{3}$. The density calculated based on the empirical formula is $3.940 \mathrm{~g} / \mathrm{cm}^{3}$.

The mineral is optically biaxial $(+)$ with optical constants measured in $\mathrm{Na}_{\mathrm{D}}$ light (589 nm): $\alpha=1.674(2), \beta=1.684(2)$, and $\gamma=1.708(2)^{\circ}$. The measured $2 V$ is $66(2)^{\circ}$, which compares well to the calculated value, $66.5^{\circ}$. Strong $r>v$ dispersion was observed. The optical orientation is $X=b, Y=c$, and $Z=a$. No pleochroism was observed. The Gladstone-Dale compatibility index $1-\left(\mathrm{K}_{\mathrm{P}} / \mathrm{K}_{\mathrm{C}}\right)$ as defined by Mandarino (1981) provides a measure of the consistency among the average index of refraction, calculated density, and chemical composition. For plumbophyllite, the compatibility index is -0.046 , indicating good agreement among these data.

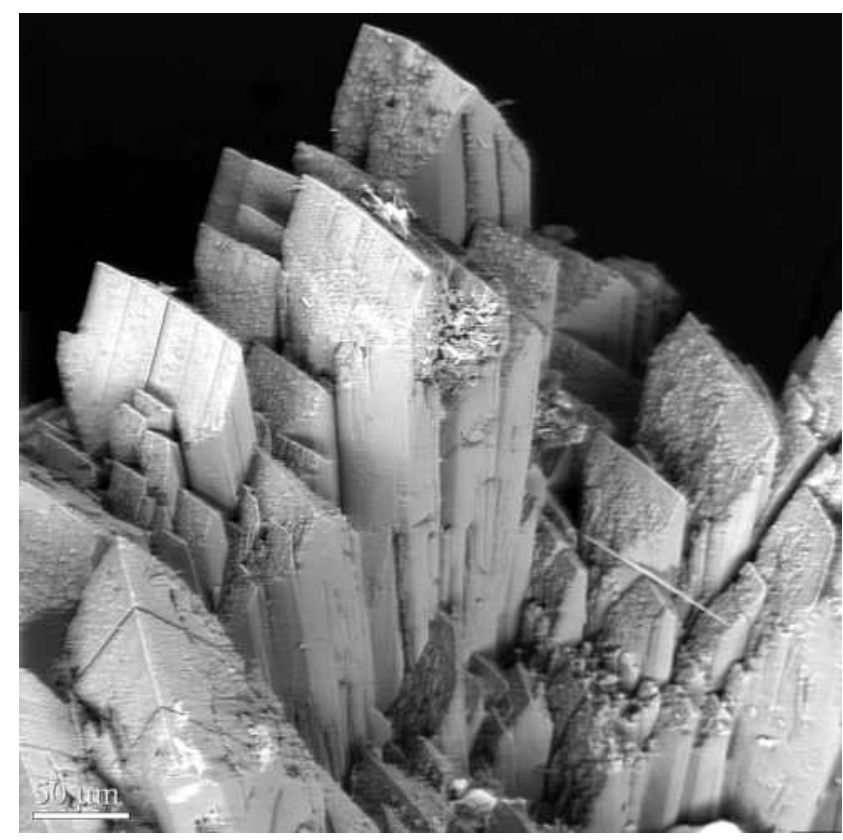

FIGURE 1. SEM back-scattered electron image of plumbophyllite. Note cleavage traces, and slight encrustations of silica and cerussite (bright). Tiny needle in middle right is pyromorphite.

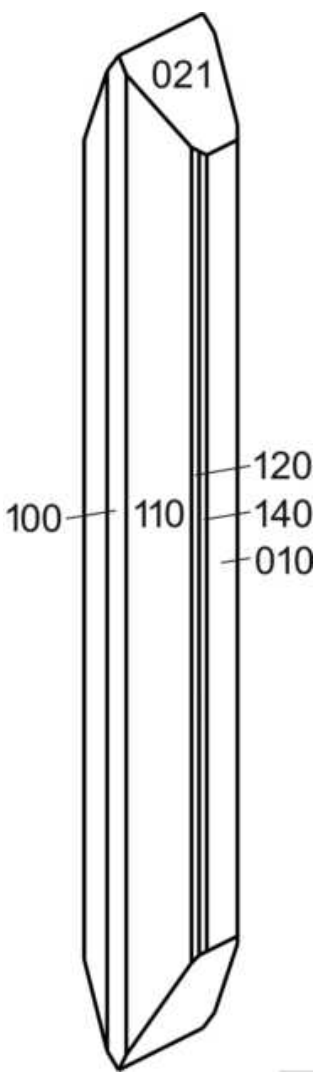

FiguRE 2. Crystal drawing of plumbophyllite (clinographic projection)

\section{CHeMistry}

Several crystals were mounted in epoxy, polished, and carbon coated. Twenty preliminary EDS analyses were conducted using a Philips XM30 FESEM equipped with an ETEC backscattered electron detector and an IMIX thin window detector and EDS 
analysis system. These confirmed the crystals to be chemically homogeneous except for variable amounts of $\mathrm{Cu}$ from less than 0.5 to about 0.8 at $\%$.

The final analyses were performed in WDS mode on a JEOL 8200 microprobe using a $15 \mathrm{KeV}$ electron beam at $25 \mathrm{nA}$. Seven analyses over four spots were obtained with beam diameters of 1,10 , and $20 \mu \mathrm{m}$. Probe standards were pyromorphite for $\mathrm{Pb}, \mathrm{Cu}$ metal for $\mathrm{Cu}$, and anorthite for $\mathrm{Si}$. The averages and ranges of the analyses in $\mathrm{wt} \%$ : $\mathrm{PbO} 60.25$ (59.24-61.27), $\mathrm{CuO}$ 0.23 (0.00-0.77), $\mathrm{SiO}_{2} 36.22$ (35.71-36.58). Two analyses on an Exeter Analytical CEC 440HA CHN analyzer provided an average $\mathrm{H}_{2} \mathrm{O}$ content of $3.29 \mathrm{wt} \%$. The total of the microprobe and $\mathrm{CHN}$ analyses is $99.99 \mathrm{wt} \%$.

The empirical formula (based on $4 \mathrm{Si} \mathrm{pfu}$ ) is $\mathrm{Pb}_{1.79} \mathrm{Cu}_{0.02} \mathrm{Si}_{4} \mathrm{O}_{9.62}$ $(\mathrm{OH})_{0.38} \cdot 1.02 \mathrm{H}_{2} \mathrm{O}$. The ideal formula is $\mathrm{Pb}_{2} \mathrm{Si}_{4} \mathrm{O}_{10} \cdot \mathrm{H}_{2} \mathrm{O}$, which requires: $\mathrm{PbO}$ 63.34, $\mathrm{SiO}_{2} 34.10, \mathrm{H}_{2} \mathrm{O}$ 2.56, total $100.00 \mathrm{wt} \%$. Plumbophyllite decomposes immediately (and dramatically) in cold, dilute $\mathrm{HCl}$ with exfoliation and formation of a white precipitate of $\mathrm{PbCl}_{2}$ (cotunnite).

\section{RAMAN AND INFRARED SPECTROSCOPY}

Infrared spectra were obtained with a Thermo-Nicolet Magna 860 FTIR operating at $4 \mathrm{~cm}^{-1}$ resolution. Attenuated total reflectance (ATR) spectra were obtained with a SensIR Durascope accessory with a diamond sample plate. Three small clusters of plumbophyllite crystals were selected for purity under a binocular microscope, transferred to a small boron carbide mortar and pestle and ground to a fine powder. A quantity of powdered sample sufficient to cover about a $1 \mathrm{~mm}$ diameter area on the ATR's diamond plate was used. The IR spectrum obtained is shown in Figure 3, and shows prominent features at $958,771,711,640,499,465$, and $439 \mathrm{~cm}^{-1}$ arising, in part, from the silicate groups. In addition to these features, a water-bending feature occurs at about $1636 \mathrm{~cm}^{-1}$ and $\mathrm{OH}$-stretching features occur in the 3700 to $3000 \mathrm{~cm}^{-1}$ range with a prominent peak at $3452 \mathrm{~cm}^{-1}$. The powder's purity was subsequently confirmed by examination in an SEM.

To investigate the orientation of the water, single-crystal IR spectra were obtained in the $\mathrm{OH}$-stretching region with a Nicolet Continuum infrared microscope. A calcium fluoride supported wire-grid was used for polarization measurements along with a $\mathrm{CaF}_{2}$ beam splitter and a MCT-A cryogenic detector. Two crystals were chosen for detailed studies. The first was a (100) cleavage slab $258 \mu \mathrm{m}$ long. Its thickness was about $24 \mu \mathrm{m}$, but not perfectly uniform. It was mounted over a $200 \mu \mathrm{m}$ diameter hole in an opaque disk. Polarization directions were determined from the optical extinction directions that correspond to the long $c$-axis of the crystal and the $b$-axis perpendicular to it. A spot $\sim 25 \times 100 \mu \mathrm{m}$ was used for the analysis. The second crystal had well-developed $\{010\}$ crystal faces. It was $70 \mu \mathrm{m}$ thick and about $120 \mu \mathrm{m}$ long.

Spectra spanning the $\mathrm{OH}$-stretching and water-bending regions were obtained with both crystals. These are normalized to a $100 \mu \mathrm{m}$ thickness in Figure 4a. The intense absorptions in the $a$ and $c$ directions show that the plane of the $\mathrm{H}_{2} \mathrm{O}$ molecule is oriented dominantly perpendicular to the $b$ axis, and the intense bending mode near $1620 \mathrm{~cm}^{-1}$ shows that the molecular twofold symmetry axis of the water is aligned predominantly along the crystallographic $c$ axis. Unfortunately, these crystals are too thick to obtain meaningful polarized spectra in the lower energy silicate region where the absorption bands are much stronger.

Spectra were also obtained in the region of the water molecule's combination stretching + bending motions near $5200 \mathrm{~cm}^{-1}$ from the same two crystals. The results in Figure $4 \mathrm{~b}$ confirm that the water molecules are structural. The two overlapping bands in the spectrum suggest that there are either two structurally distinct water molecules or two non-equivalent water-bending motions involving the coupled motion of multiple water molecules.

Following the IR work, Raman spectroscopic micro-analysis on the same crystal was carried out using a Renishaw M1000 micro-Raman spectrometer system. Light from a $514.5 \mathrm{~nm}$ laser was focused onto the sample with a $100 \times$ objective lens, and provided $\sim 5 \mathrm{mw}$ of power at the sample. The spot size was about $1.5 \mu \mathrm{m}$. Peak positions were calibrated against a silicon standard. All spectra were obtained with a dual-wedge polarization scrambler inserted directly above the objective lens to minimize the effects of polarization. Spectra showing both the silicate and $\mathrm{OH}$-stretching regions are shown in Figure 5. Prominent Raman features are observed at 3561, 3468, 3338, $3209,1062,1024,980,923,641,506,480,347,329,251,209$, 146 , and $94 \mathrm{~cm}^{-1}$ shifts.

\section{X-RAY CRYSTALLOGRAPHY AND STRUCTURE DETERMINATION}

Both powder and single-crystal X-ray diffraction data were obtained on a Rigaku R-Axis Spider curved imaging plate microdiffractometer utilizing monochromatized $\mathrm{MoK \alpha}$ radiation. The powder data presented in Table 1 show good agreement with the pattern calculated from the structure determination.

The Rigaku Crystal Clear software package was used for processing of the structure data. The SHELXL97 software (Sheldrick 1997) was used for the solution and refinement of the structure. The structure was solved by direct methods. The location of $\mathrm{Pb}, \mathrm{Si}$, and $\mathrm{O}$ atoms was straightforward. With all non-hydrogen atoms located and refined anisotropically at full occupancies, the refinement converged to $R_{1}=1.92 \%$ and $\mathrm{w} R_{2}$ $=3.91 \%$ for 1188 reflections with $F_{\mathrm{o}}>4 \sigma\left(F_{\mathrm{o}}\right)$.

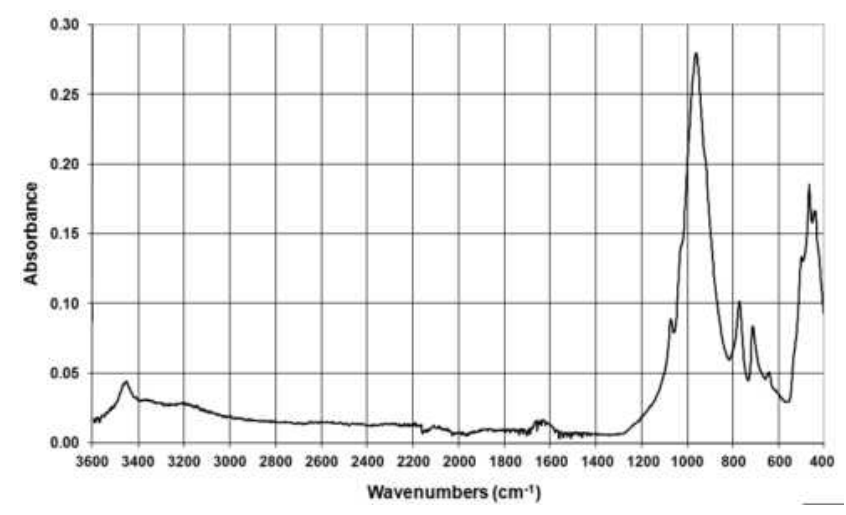

FIGURE 3. Attenuated total reflection IR spectrum of a sub milligram quantity of finely powdered plumbophyllite. Note in addition to silicate features at lower wavenumber also the weak molecular water-bending feature at about $1630 \mathrm{~cm}^{-1}$ and the $\mathrm{OH}$-stretching features at about $3300 \mathrm{~cm}^{-1}$. 


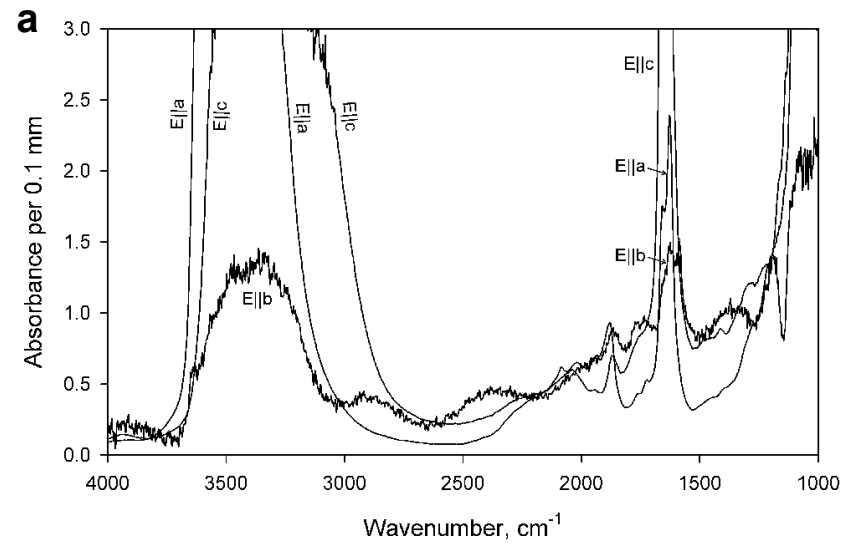

b

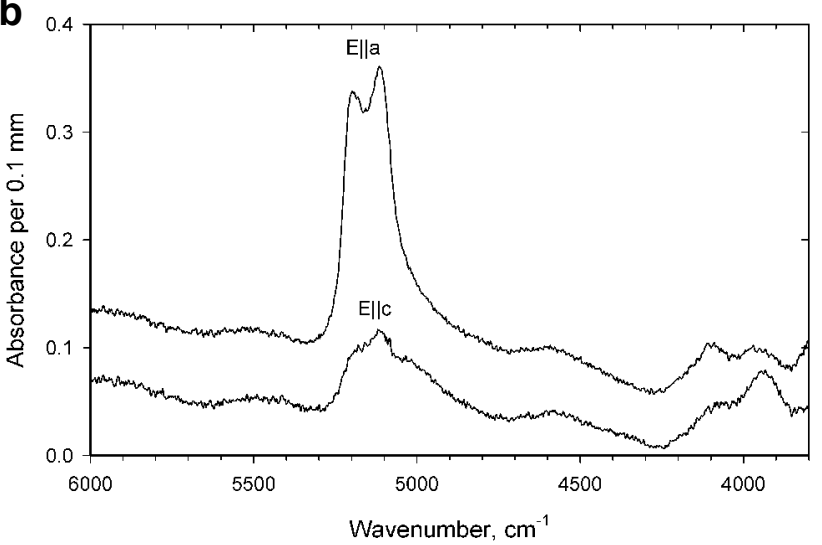

FIGURE 4. Polarized transmission IR spectra of plumbophyllite single crystals: (a) infrared region showing $\mathrm{OH}$-stretching and water-bending, and (b) near-infrared region showing the water molecule's combination stretching + bending motions. Note that The $E \| b$ direction is devoid of absorption in the $5150 \mathrm{~cm}^{-1}$ region.

One $\mathrm{O}$ atom, $\mathrm{OW}$, participates in bonding to $\mathrm{Pb}$ only and is clearly a water molecule. The $\mathrm{OW}$ atomic displacement parameters (ADPs), particularly $U_{33}$, were relatively large $\left[U_{\text {eq }}=\right.$ $0.157(5)$ and $U_{33}=0.31(2)$ ], suggesting that this site is disordered along the $c$ axis (channel direction). Efforts to improve the refinement by splitting the site were not very successful. The most reasonable ADPs $\left[U_{\text {eq }}=0.071(5)\right.$ and $\left.U_{33}=0.16(2)\right]$ were obtained by setting the occupancy of the site to 0.5 . This occupancy was used in the final refinement, even though the resulting $R_{1}$ and $\mathrm{w} R_{2}$ increased to $2.04 \%$ and $4.81 \%$, respectively.

Based upon O-O distances and bond valence sums, likely $\mathrm{H}$-bonds are between adjacent half-occupied OW sites [2.52(4) and 2.53(3) $\AA$ ] and between OW and O2 [2.790(9) $\AA]$. The difference Fourier map showed several peaks near OW that could correspond to the positions of $\mathrm{H}$ atoms; however, refinement attempts with various combinations of these positions did not yield unambiguous $\mathrm{H}$ atom sites.

The details of the data collection and structure refinement are provided in Table 2 . The final atomic coordinates and equivalent isotropic displacement parameters are in Table 3 and the anisotropic displacement parameters in Table 4. Selected interatomic distances are listed in Table 5 and bond valences in Table 6 . The observed and calculated structure amplitudes are on deposit. ${ }^{1}$

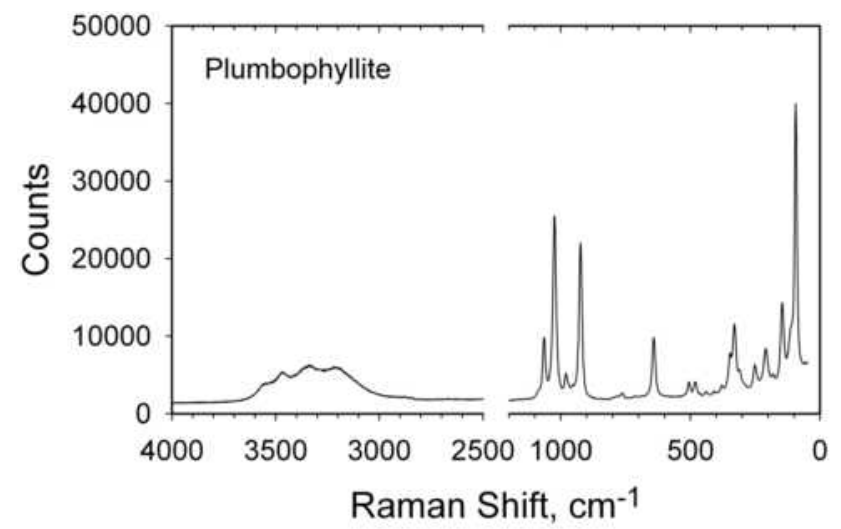

FIGURE 5. Unpolarized Raman spectra of plumbophyllite showing both the silicate region on the right and the $\mathrm{OH}$-stretching region on the left.

\section{DESCRIPTION OF THE STRUCTURE}

Plumbophyllite has a unique phyllosilicate structure (Fig. 6) consisting of undulating sheets of silicate tetrahedra parallel to $\{100\}$ joined via bonds to interlayer $\mathrm{Pb}$ cations. Channels in this $\mathrm{Pb}$-silicate network parallel to the $c$ axis contain $\mathrm{H}_{2} \mathrm{O}$ molecules bonded to $\mathrm{Pb}$.

\section{Pb coordination}

Lead $(\mathrm{Pb})$ exhibits "lop-sided" 7-coordination with four short bonds to $\mathrm{O}$ atoms in the silicate sheet on one side and three long bonds to $\mathrm{O}$ atoms on the opposite side. Two of the long $\mathrm{Pb}-\mathrm{O}$ bonds are to $\mathrm{O}$ atoms on the periphery of the channels and one long bond is to the water molecule, OW, at the center of the channel. The "lop-sided" coordination is consistent with that exhibited by $\mathrm{Pb}$ in many structures and is in response to the $\mathrm{Pb}$ lone-pair electrons, which reside on the side of the $\mathrm{Pb}$ corresponding to the long bonds. In plumbophyllite, the $\mathrm{Pb}$ lone-pair electrons are accommodated in the channels of structure. The hardness of the mineral is quite high for a phyllosilicate indicating that the short $\mathrm{Pb}-\mathrm{O}$ bonds are unusually strong and hold the layers tightly together.

\section{Silicate sheet}

The sheets of silicate tetrahedra can be described as consisting of zigzag pyroxene-like $\left(\mathrm{SiO}_{3}\right)_{\mathrm{n}}$ chains joined laterally into sheets with the unshared tetrahedral apices in successive chains pointed alternately up and down (Fig. 7). The tetrahedral network is characterized by 6-member rings. Silicate sheets based on 6-member rings are found in many phyllosilicates; however, in the vast majority of these, the apical $\mathrm{O}$ atoms are all oriented in the same direction. Another distinguishing feature of the silicate

\footnotetext{
${ }^{1}$ Deposit item AM-09-036, observed and calculated structure amplitudes and CIF. Deposit items are available two ways: For a paper copy contact the Business Office of the Mineralogical Society of America (see inside front cover of recent issue) for price information. For an electronic copy visit the MSA web site at http://www.minsocam.org, go to the American Mineralogist Contents, find the table of contents for the specific volume/issue wanted, and then click on the deposit link there.
} 
TABLE 1. Observed and calculated X-ray powder-diffraction data for plumbophyllite

\begin{tabular}{|c|c|c|c|c|c|c|c|c|c|c|c|c|c|c|}
\hline lobs & $d_{\text {obs }}$ & $d_{\text {calc }}$ & $I_{\text {calc }}$ & $h k l$ & $I_{\text {obs }}$ & $d_{\text {obs }}$ & $d_{\text {calc }}$ & $I_{\text {calc }}$ & hkl & $I_{\text {obs }}$ & $d_{\mathrm{obs}}$ & $d_{\text {calc }}$ & $I_{\text {calc }}$ & hkl \\
\hline 97 & 7.883 & 7.8616 & 100 & 110 & \multirow{3}{*}{25} & \multirow{3}{*}{2.082\{} & 2.0845 & 26 & 611 & 11 & 1.524 & 1.5239 & 10 & 543 \\
\hline 35 & 6.625 & 6.6041 & 44 & 200 & & & 2.0756 & 15 & 341 & 5 & 1.503 & 1.5027 & 5 & 723 \\
\hline 27 & 5.825 & 5.8191 & 25 & 111 & & & 2.0561 & 5 & 204 & 12 & 1.472 & 1.4722 & 16 & 741 \\
\hline 38 & 4.897 & 4.8916 & 43 & 020 & \multirow[t]{2}{*}{12} & 2.054 & 2.0527 & 8 & 530 & \multirow{3}{*}{9} & \multirow{3}{*}{1.443\{} & 1.4443 & 3 & 335 \\
\hline 20 & 4.629 & 4.6261 & 21 & 211 & & & 2.0449 & 4 & 432 & & & 1.4425 & 5 & 154 \\
\hline 30 & 4.323 & 4.3273 & 29 & 002 & 5 & 1.979 & 1.9787 & 7 & 024 & & & 1.4178 & 4 & 813 \\
\hline 26 & 3.933 & 3.9308 & 34 & 220 & \multirow{2}{*}{15} & \multirow{2}{*}{1.938\{} & 1.9418 & 4 & 304 & \multirow[t]{2}{*}{7} & \multirow{2}{*}{1.418\{} & 1.4174 & 2 & 254 \\
\hline 15 & 3.791 & 3.7909 & 19 & 112 & & & 1.9355 & 17 & 150 & & & 1.4129 & 3 & 045 \\
\hline 100 & 3.623 & 3.6195 & 89 & 202 & \multirow{2}{*}{5} & \multirow{2}{*}{1.903\{} & 1.9107 & 5 & 513 & \multirow{2}{*}{11} & \multirow{2}{*}{1.394\{} & 1.3948 & 7 & 634 \\
\hline 2 & 3.398 & 3.3946 & 4 & 212 & & & 1.8955 & 4 & 224 & & & 1.3944 & 4 & 832 \\
\hline 17 & 3.302 & 3.3021 & 34 & 400 & 9 & 1.863 & 1.8656 & 8 & 043 & \multirow{2}{*}{15} & \multirow{2}{*}{1.383\{} & 1.3875 & 6 & 921 \\
\hline 14 & 3.246 & 3.2411 & 17 & 022 & \multirow{4}{*}{9} & \multirow{4}{*}{1.808\{} & 1.8100 & 4 & 523 & & & 1.3816 & 12 & 245 \\
\hline 45 & 3.166 & 3.1660 & 55 & 130 & & & 1.8097 & 3 & 404 & \multirow{3}{*}{6} & \multirow{3}{*}{1.369} & 1.3700 & 5 & 561 \\
\hline 22 & 3.062 & 3.0609 & 28 & 321 & & & 1.8080 & 4 & 433 & & & 1.3655 & 2 & 724 \\
\hline & & 2.9432 & 13 & 312 & & & 1.7953 & 6 & 243 & & & 1.3286 & 2 & 454 \\
\hline \multirow[t]{2}{*}{57} & 2.938 & 2.9423 & 45 & 411 & \multirow{3}{*}{18} & \multirow{3}{*}{1.788\{} & 1.7880 & 7 & 350 & \multirow[t]{2}{*}{4} & \multirow[t]{2}{*}{1.326} & 1.3266 & 3 & 743 \\
\hline & & 2.9096 & 37 & 222 & & & 1.7863 & 9 & 134 & & & 1.3233 & 1 & 172 \\
\hline 6 & 2.769 & 2.7702 & 6 & 231 & & & 1.7853 & 6 & 631 & \multirow[t]{2}{*}{6} & 1.295 & 1.2942 & 6 & $10,1,1$ \\
\hline 23 & 2.711 & 2.7369 & 10 & 420 & 15 & & 1.7668 & 15 & 152 & & & 1.2731 & 1 & 372 \\
\hline 23 & 2.711\{ & 2.7083 & 21 & 113 & 15 & 1.102 & 1.7573 & 13 & 541 & 3 & 1.272 & 1.2731 & 3 & 471 \\
\hline 29 & 2623\{ & 2.6251 & 13 & 402 & & 173 & 1.7251 & 12 & 721 & & & 1.2719 & 2 & 554 \\
\hline 29 & & 2.6205 & 16 & 330 & 20 & 1.724 & 1.7227 & 14 & 613 & 3 & 1.265 & 1.2660 & 3 & 506 \\
\hline & $2555\}$ & 2.5551 & 36 & 132 & 10 & 1.690 & 1.6904 & 14 & 115 & & 1246 & 1.2504 & 2 & 563 \\
\hline 51 & 2.555\{ & 2.5521 & 12 & 213 & & & 1.6738 & 5 & 504 & 3 & 1.246 & 1.2453 & 5 & 941 \\
\hline 4 & 2.487 & 2.4849 & 4 & 023 & 7 & $1.6 \%$ & 1.6684 & 4 & 334 & & & 1.2250 & 3 & 436 \\
\hline & & 2.3428 & 13 & 313 & 10 & 1.651 & 1.6525 & 13 & 352 & & & 1.2229 & 3 & 080 \\
\hline 22 & $2.322\}$ & 2.3257 & 11 & 223 & & & 1.6318 & 4 & 025 & 13 & 1.222 & 1.2214 & 4 & 761 \\
\hline & & 2.3131 & 15 & 422 & 7 & 1.628 & 1.6307 & 2 & 722 & & & 1.2213 & 6 & 117 \\
\hline 50 & 2243\{ & 2.2448 & 12 & 521 & & & 1.6243 & 4 & 443 & & & & & \\
\hline 30 & 2.243\{ & 2.2415 & 32 & 332 & 13 & 1.596 & 1.6000 & 17 & 811 & & & & & \\
\hline & & 2.1640 & 5 & 323 & & & 1.5895 & 9 & 315 & & & & & \\
\hline 7 & 2.164\{ & 2.1636 & 4 & 004 & 22 & 1.586 & 1.5841 & 5 & 225 & & & & & \\
\hline 8 & 2.126 & 2.1209 & 8 & 413 & & & 1.5837 & 5 & 524 & & & & & \\
\hline
\end{tabular}

Notes: The calculated $d$ spacings are based upon the cell refined from the structure data. The calculated intensities are based upon the structure determination.

TABLE 2. Data collection and structure refinement details for plumbophyllite

\begin{tabular}{|c|c|}
\hline Diffractometer & $\begin{array}{l}\text { Rigaku R-Axis Spider with curved imaging } \\
\text { plate }\end{array}$ \\
\hline X-ray radiation/power & $\operatorname{MoK} \alpha(\lambda=0.71075 \AA) / 50 \mathrm{kV}, 40 \mathrm{~mA}$ \\
\hline Temperature & $298(2) \mathrm{K}$ \\
\hline Formula & $\mathrm{Pb}_{2} \mathrm{Si}_{4} \mathrm{O}_{10} \cdot \mathrm{H}_{2} \mathrm{O}$ \\
\hline Space group & Pbcn \\
\hline Unit-cell dimensions & $\begin{array}{l}a=13.2083(4) \AA \\
b=9.7832(3) \AA \\
c=8.6545(2) \AA\end{array}$ \\
\hline$z$ & 4 \\
\hline Volume & $1118.32(5) \AA^{3}$ \\
\hline Density (for ideal formula) & $4.185 \mathrm{~g} / \mathrm{cm}^{3}$ \\
\hline Absorption coefficient & $122.18 \mathrm{~mm}^{-1}$ \\
\hline$F(000)$ & 4960 \\
\hline Crystal size & $0.30 \times 0.06 \times 0.02 \mathrm{~mm}$ \\
\hline$\theta$ range & 3.08 to $27.46^{\circ}$ \\
\hline Index ranges & $-17 \leq h \leq 17,-12 \leq k \leq 12,-11 \leq I \leq 9$ \\
\hline Reflections collected/unique & $13872 / 1273\left[R_{\text {int }}=0.0409\right]$ \\
\hline Completeness to $\theta=27.46^{\circ}$ & $99.2 \%$ \\
\hline Refinement method & Full-matrix least-squares on $\mathrm{F}^{2}$ \\
\hline Parameters refined & 82 \\
\hline GooF & 1.084 \\
\hline Final $R$ indices $\left[F_{\mathrm{o}}>4 \sigma\left(F_{\mathrm{o}}\right)\right]$ & $R_{1}=0.0204, \mathrm{w} R_{2}=0.0481$ \\
\hline$R$ indices (all data) & $R_{1}=0.0228, \mathrm{w} R_{2}=0.0491$ \\
\hline Largest diff. peak/hole & $+1.90 /-0.836 \mathrm{e} / \mathrm{A}^{3}$ \\
\hline \multicolumn{2}{|c|}{$\begin{array}{l}\text { Notes: } R_{\text {int }}=\Sigma \mid F_{0}^{2}-F_{0}^{2}(\text { mean }) \mid / \Sigma\left[F_{0}^{2}\right] . G o o F=S=\left\{\Sigma\left[w\left(F_{0}^{2}-F_{c}^{2}\right)^{2}\right] /(n-p)\right\}^{1 / 2} \cdot R_{1}=\Sigma \| F_{o} \\
-\left|F_{c}\right||\Sigma| / F_{o} \mid \cdot w R_{2}=\left\{\Sigma\left[w\left(F_{0}^{2}-F_{c}^{2}\right)^{2}\right] / \Sigma\left[w\left(F_{0}^{2}\right)^{2}\right]\right\}^{1 / 2} \cdot W=1 /\left[\sigma^{2}\left(F_{0}^{2}\right)+(a P)^{2}+b P\right] \text { where } c \\
\text { is } 0.0196, b \text { is } 9.4378, \text { and } P \text { is }\left[2 F_{c}^{2}+\operatorname{Max}\left(F_{0}^{2}, 0\right)\right] / 3 \text {. }\end{array}$} \\
\hline
\end{tabular}

sheet in plumbophyllite is that its basal (shared) $\mathrm{O}$ atoms are not coplanar and deviate significantly from the nearly ideal hexagonal mesh pattern that is typical of this defect close-packed layer in many phyllosilicates.

The structure of the phyllosilicate pentagonite, $\mathrm{Ca}(\mathrm{VO})$ $\left(\mathrm{Si}_{4} \mathrm{O}_{10}\right) \cdot 4 \mathrm{H}_{2} \mathrm{O}$, (Evans 1973) is somewhat similar to that of
TABLE 3. Atomic coordinates, site occupancies, and equivalent isotropic displacement parameters $\left(\AA^{2}\right)$ for plumbophyllite

\begin{tabular}{lllll}
\hline Atom & \multicolumn{1}{c}{$x$} & \multicolumn{1}{c}{$y$} & \multicolumn{1}{c}{$z$} & \multicolumn{1}{c}{$U_{\text {eq }}$} \\
\hline $\mathrm{Pb}$ & $0.53131(1)$ & $0.18997(2)$ & $0.46446(2)$ & $0.01220(8)$ \\
$\mathrm{Si} 1$ & $0.2749(1)$ & $0.1825(1)$ & $0.3184(2)$ & $0.0071(3)$ \\
$\mathrm{Si} 2$ & $0.3044(1)$ & $0.0755(1)$ & $0.6398(2)$ & $0.0072(3)$ \\
$\mathrm{O} 1$ & $0.3926(3)$ & $0.2162(4)$ & $0.3017(5)$ & $0.0134(8)$ \\
$\mathrm{O} 2$ & $0.2433(3)$ & $-0.0594(4)$ & $0.6989(4)$ & $0.0118(7)$ \\
$\mathrm{O} 3$ & $0.2996(3)$ & $0.1899(4)$ & $0.7771(5)$ & $0.0135(8)$ \\
$\mathrm{O} 4$ & $0.2416(3)$ & $0.1370(4)$ & $0.4927(4)$ & $0.0108(7)$ \\
$\mathrm{O} 5$ & $0.4179(3)$ & $0.0378(4)$ & $0.5937(5)$ & $0.0140(8)$ \\
$\mathrm{OW}$ & $0.4610(7)$ & $0.4439(13)$ & $0.6173(22)$ & $0.071(5)$ \\
\hline
\end{tabular}

TABLE 4. Anisotropic displacement parameters $\left(\AA^{2}\right)$ for plumbophyllite

\begin{tabular}{lllllll}
\hline Atom & $U_{11}$ & $U_{22}$ & \multicolumn{1}{c}{$U_{33}$} & $U_{23}$ & $U_{13}$ & \multicolumn{1}{c}{$U_{12}$} \\
\hline $\mathrm{Pb}$ & $0.0096(1)$ & $0.0135(1)$ & $0.0135(1)$ & $-0.00134(7)$ & $0.00015(7)$ & $0.00025(7)$ \\
$\mathrm{Si} 1$ & $0.0071(6)$ & $0.0067(6)$ & $0.0075(7)$ & $0.0005(5)$ & $0.0004(5)$ & $0.0009(5)$ \\
$\mathrm{Si} 2$ & $0.0070(6)$ & $0.0070(6)$ & $0.0075(7)$ & $-0.0002(5)$ & $0.0012(5)$ & $0.0015(5)$ \\
$\mathrm{O} 1$ & $0.011(2)$ & $0.017(2)$ & $0.012(2)$ & $0.002(1)$ & $0.000(1)$ & $-0.001(1)$ \\
$\mathrm{O} 2$ & $0.012(2)$ & $0.011(2)$ & $0.013(2)$ & $0.003(1)$ & $0.001(1)$ & $-0.001(1)$ \\
$\mathrm{O} 3$ & $0.015(2)$ & $0.013(2)$ & $0.013(2)$ & $-0.003(1)$ & $-0.005(1)$ & $0.006(1)$ \\
$\mathrm{O} 4$ & $0.012(2)$ & $0.014(2)$ & $0.006(2)$ & $0.004(1)$ & $0.002(1)$ & $0.001(1)$ \\
$\mathrm{O} 5$ & $0.011(2)$ & $0.012(2)$ & $0.019(2)$ & $0.003(1)$ & $0.005(2)$ & $0.004(1)$ \\
$\mathrm{OW}$ & $0.012(5)$ & $0.043(7)$ & $0.159(15)$ & $-0.026(8)$ & $0.043(7)$ & $0.007(5)$ \\
\hline
\end{tabular}

plumbophyllite. The silicate sheets in pentagonite, although based on the typical hexagonal mesh pattern of basal $\mathrm{O}$ atoms, has the same alternating up-and-down configuration of apical $\mathrm{O}$ atoms as plumbophyllite (Fig. 7). Furthermore, adjacent tetrahedral sheets in both structures are bound together by relatively strong bonds between interlayer cations and the apical $\mathrm{O}$ atoms. In pentagonite, the interlayer cations are $\mathrm{Ca}$ and $\mathrm{V}$. The large size 
TABLE 5. Selected bond distances $(\AA ̊)$ for plumbophyllite

\begin{tabular}{llllll}
\hline $\mathrm{Pb}-\mathrm{O} 1$ & $2.325(4)$ & $\mathrm{Si1}-\mathrm{O} 1$ & $1.595(4)$ & $\mathrm{Si} 2-\mathrm{O} 5$ & $1.595(4)$ \\
$\mathrm{Pb}-\mathrm{O} 5$ & $2.382(4)$ & $\mathrm{Si} 1-\mathrm{O} 3$ & $1.629(4)$ & $\mathrm{Si2}-\mathrm{O} 2$ & $1.629(4)$ \\
$\mathrm{Pb}-\mathrm{O} 5$ & $2.389(4)$ & $\mathrm{Si1}-\mathrm{O} 4$ & $1.633(4)$ & $\mathrm{Si2}-\mathrm{O} 4$ & $1.634(4)$ \\
$\mathrm{Pb}-\mathrm{O} 1$ & $2.526(4)$ & $\mathrm{Si1}-\mathrm{O} 2$ & $1.642(4)$ & $\mathrm{Si2}-\mathrm{O} 3$ & $1.634(4)$ \\
$\mathrm{Pb}-\mathrm{OW}$ & $2.963(12)$ & <i1-O & 1.625 & <Si2-O & 1.622 \\
$\mathrm{~Pb}-\mathrm{O} 3$ & $3.161(4)$ & & & & \\
$\mathrm{Pb}-\mathrm{O} 4$ & $3.273(4)$ & & & & \\
\hline
\end{tabular}

TABLE 6. Bond valence summations for plumbophyllite

\begin{tabular}{lccccccc}
\hline & $\mathrm{O} 1$ & $\mathrm{O} 2$ & $\mathrm{O} 3$ & $\mathrm{O} 4$ & $\mathrm{O} 5$ & $\mathrm{OW}$ & $\Sigma_{c} V$ \\
\hline $\mathrm{Pb}$ & 0.562 & & 0.059 & 0.043 & 0.482 & $0.100 \times 1 / 2>$ & 1.996 \\
& 0.327 & & & & 0.473 & & \\
$\mathrm{Si} 1$ & 1.082 & 0.953 & 0.987 & 0.976 & & & 3.997 \\
$\mathrm{Si} 2$ & & 0.987 & 0.973 & 0.973 & 1.082 & & 4.015 \\
$\Sigma_{\mathrm{a} V}$ & 1.970 & 1.939 & 2.019 & 1.993 & 2.037 & 0.100 &
\end{tabular}

Notes: Bond strengths from Brese and O'Keeffe (1991); valence summations are expressed in valence units. Contributions by the $\mathrm{H}$ atoms have not been included.

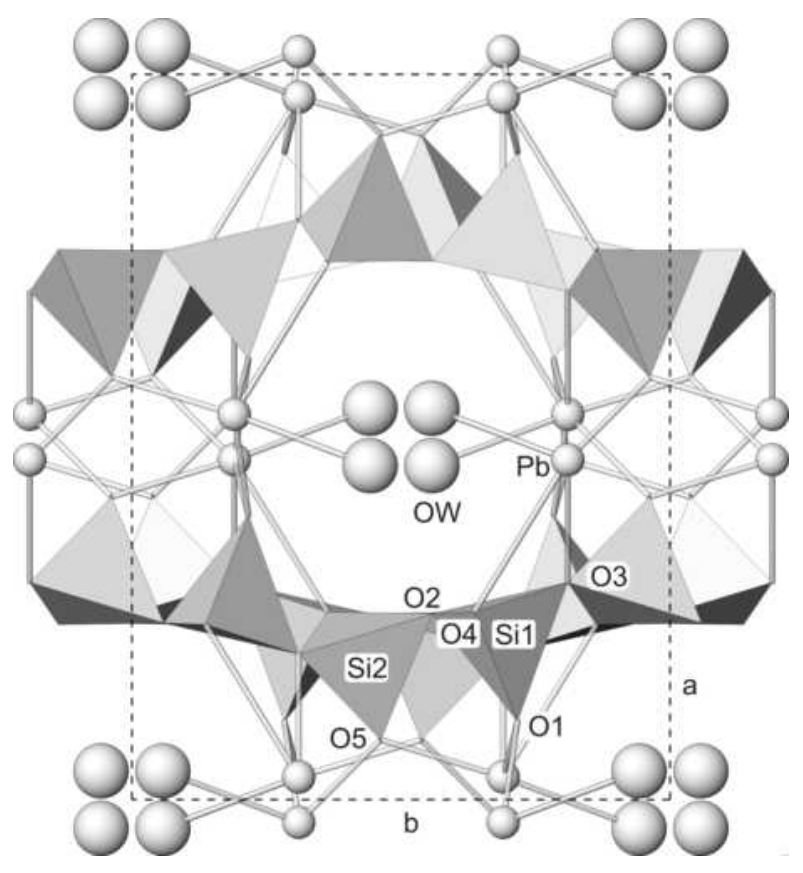

FIGURE 6. Crystal structure of plumbophyllite viewed down $c$.

of the $\mathrm{Pb}$ cation and its tendency toward off-center coordination may be factors contributing to the distortion of the silicate sheet in plumbophyllite.

\section{Hydrogen bonding scheme}

The OW site in the channel is half-occupied by the $\mathrm{O}$ atom of an $\mathrm{H}_{2} \mathrm{O}$ molecule. The most likely recipients of hydrogen bonds are $\mathrm{O}$ atoms at adjacent $\mathrm{OW}$ sites (at 2.52 and $2.53 \AA$ ) and the $\mathrm{O}$ atom at $\mathrm{O} 2$ (at $2.79 \AA$ ). A hypothetical hydrogen-bond network (oriented essentially parallel to the $a-c$ plane) is shown in Figure 8 . In such a scheme, each half-occupied OW could participate in three differently oriented $\mathrm{H}_{2} \mathrm{O}$ molecules, labeled 1, 2, and 3 in Figure 8 . Bond valence calculations for hydrogen bonding based upon O-O distances (Brown and Altermatt 1985) indicate that for
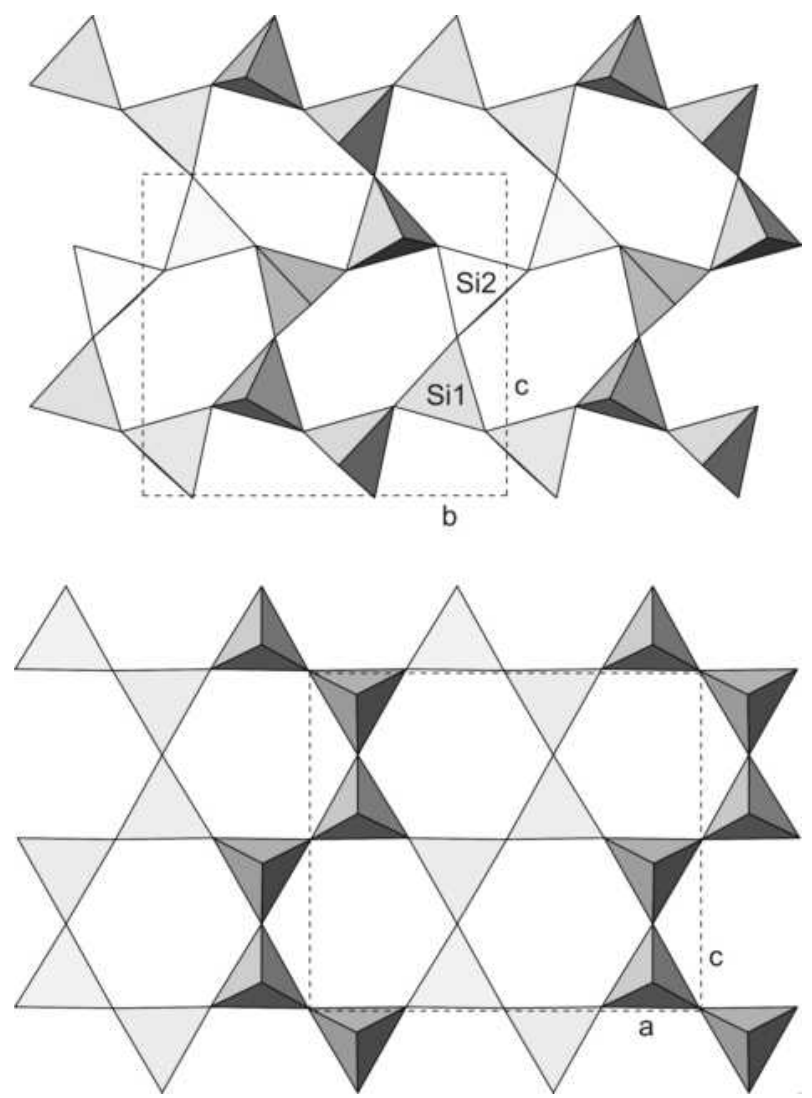

FIGURE 7. Silicate sheets in plumbophyllite (top) and pentagonite (bottom)

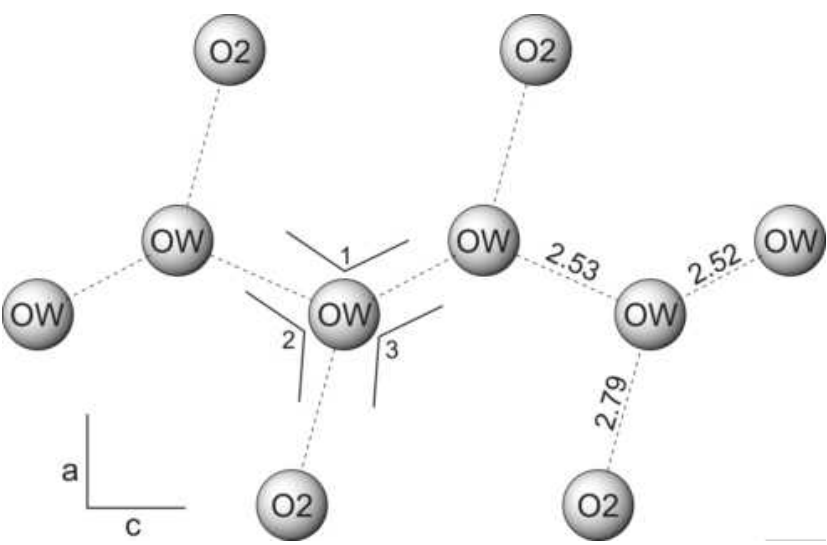

FIGURE 8. Possible $\mathrm{H}$ bonding scheme in plumbophyllite. The three possible orientations for $\mathrm{H}_{2} \mathrm{O}$ molecules are indicated by 1,2 , and 3 . Orientation 1 is deemed unlikely for bond valence reasons.

orientation 1 in which the $\mathrm{H}_{2} \mathrm{O}$ has both of its $\mathrm{H}$ atoms oriented toward adjacent OW sites, the very short OW-OW distances would theoretically yield very strong hydrogen bonds, leaving the central $\mathrm{O}$ atom with a very low bond valence sum of $\sim 1.52$ (including the contribution from $\mathrm{Pb}$ ). In orientations 2 and 3 , in which the $\mathrm{H}_{2} \mathrm{O}$ forms hydrogen bonds to one adjacent $\mathrm{OW}$ and to an $\mathrm{O} 2$, the bond valence sums for the central $\mathrm{O}$ atom would be 1.84 and 1.80 , respectively. The existence of these two orientations for the water molecules in the channel is consistent with the evidence from the polarized IR spectra noted above. 


\section{ACKNOWLEDGMENTS}

Joe Marty and Brent Thorne are thanked for providing the specimens of plumbophyllite used in this study. The IR and Raman spectroscopy as well as the microprobe analyses were supported by a grant to Caltech from the Northern California Mineralogical Association. The remainder of this study was funded by the John Jago Trelawney Endowment to the Mineral Sciences Department of the Natural History Museum of Los Angeles County. Stephen J. Guggenheim and Sergey Krivovichev provided helpful comments on the structure.

\section{REFERENCES CITED}

Brese, N.E. and O'Keeffe, M. (1991) Bond-valence parameters for solids. Acta Crystallographica, B47, 192-197.

Brown, I.D. and Altermatt, D. (1985) Bond-valence parameters obtained from a systematic analysis of the Inorganic Crystal Structure Database. Acta Crystallographica, B41, 244-247.

Burns, P. (2000) Quetzalcoatlite: A new octahedral-tetrahedral structure from a 2 $\times 2 \times 40 \mathrm{~mm}^{3}$ crystal at the Advanced Photon Source-GSE-CARS Facility. American Mineralogist, 85, 604-607.

Crowley, J.A. (1977) Minerals of the Blue Bell mine, San Bernardino County, California. Mineralogical Record, 8, 494-496 and 518.

Evans, H.T. (1973) The crystal structures of cavansite and pentagonite. American Mineralogist, 58, 412-424.

Goodwin, J. (1957) Outline geologic map of California, showing locations of mines with lead and zinc production. California Journal of Mines and Geol- ogy, 53, 357-724

Housley, R.M. (1997) Recent discoveries of tlalocite, kuksite, and other rare minerals from the Blue Bell mine, San Bernardino County, California. San Bernardino County Museum Association Quarterly, 44, 9-12.

Mandarino, J.A. (1981) The Gladstone-Dale relationship: Part IV. The compatibility concept and its application. Canadian Mineralogist, 19, 441-450.

Maynard, M.F., Valenti, A., Jenkins, J., Jenkins, F., Hall, D., Hall, J., White, B., White, S., Mansfield, M., and Mansfield, E. (1984) The Blue Bell Claims. San Bernardino County Museum Special Publication.

Murdoch, J. and Webb, R.W. (1956) Minerals of California. California Division of Mines and Geology Bulletin, 173, $452 \mathrm{p}$.

Sheldrick, G.M. (1997) SHELXL97. Program for the refinement of crystal structures. University of Göttigen, Germany.

Vredenburgh, L.M. (1994) Fort Irwin and vicinity: History of mining development. In R.E. Reynolds, Ed., Off Limits in the Mojave Desert. San Bernardino County Museum Association Special Publication, 94, 81-90.

Wright, L.A., Stewart, R.M., Gay Jr., T.E., and Hazenbush, G.C. (1953) Mines and mineral deposits of San Bernardino County, California. California Journal of Mines and Geology, 49, 49-192.

MANUSCRIPT RECEIVED NOVEMBER 24, 2008

MANUSCRIPT ACCEPTED MARCH 30, 2009

MANUSCRIPT HANDLED BY ANTON CHAKHMOURADIAN 